Nutrition Research Reviews, published annually by Cambridge University Press, presents authoritative and critical reviews' of research that advance new concepts and encourage fresh thinking on a variety of nutritional problems. The journal's main objective is to encourage the exchange of fundamental ideas on nutritional well-being. The subscription (excluding VAT) to volume 8,1995 , is $£ 49$ including postage (US $\$ 89$ in USA, Canada and Mexico).

The Proceedings of the Nutrition Society, published by Cambridge University Press, in part record meetings of the Symposium type, at which experts in a particular field are invited by Council to make contributions on specific parts of it and at which general discussion follows these invited contributions. The meetings also include sessions at which papers are communicated by members and others on original work. It is proposed at present to publish summaries of the papers read at each meeting, each communication being recorded in the Society's Proceedings by means of an abstract not exceeding in length $\mathbf{4 0 0}$ words or the equivalent space in print. The Proceedings are published three times a year.

The subscription (excluding VAT) to the Proceedings is $£ 126.00$ (US $\$ 240.00$ in USA, Canada and Mexico). Single issues are $£ 44.00$ (US $\$ 85.00$ in the USA, Canada and Mexico) each; postage extra.

Copying. This journal is registered with the Copyright Clearance Center, 222 Rosewood Drive, Danvers, MA 01923. Organizations in the USA who are also registered with C.C.C. may therefore copy material (beyond the limits permitted by sections 107 and 108 of the US copyright law) subject to payment to C.C.C. of the per-copy fee of $\$ 11.00$. This consent does not extend to multiple copying for promotional or commercial purposes. Code $0007-1145 / 95 \$ 11.00+.10$. Organizations authorized by the Copyright Licensing Agency may also copy material subject to the usual conditions.

ISI Tear Sheet Service, 3501 Market Street, Philadelphia, Pennsylvania 19104, USA, is authorized to supply single copies of separate articles for private use only.

For all other use, permission should be sought from Cambridge or the American Branch of Cambridge University Press.

\title{
INDEX OF AUTHORS
}

\begin{tabular}{|c|c|c|c|c|c|}
\hline Alfaham, M. & 881 & \multirow[t]{2}{*}{ Grant, G. } & \multirow[t]{2}{*}{819} & \multirow{2}{*}{$\begin{array}{l}\text { O'Brien, N. M. } \\
\text { Ørskov, E. R. }\end{array}$} & \multirow{2}{*}{$\begin{array}{l}841 \\
829\end{array}$} \\
\hline Alférez, M. J. M. & 871 & & & & \\
\hline Bardócz, S. & 819 & Hartiti, S. & 871 & Pallarés, I. & 871 \\
\hline Barrionuevo, M. & 871 & & & Pask, G. & 881 \\
\hline Baumont, R. & 793 & Isler, D. & 851 & Pusztai, A. & 819 \\
\hline Becker, K. & 897 & & & & \\
\hline Berner, Y. & 889 & Kedar, O. & 889 & Ralph, A. & 819 \\
\hline Beynen, A. C. & 863 & King, R. H. & 809 & & \\
\hline Blümmel, M. & 897 & Kyle, D. J. & 829 & Sklan, D. & 889 \\
\hline Brown, D. S. & 819 & Lawlor, S. M. & 841 & Southgate, D. A. T. & 791 \\
\hline Campos, M. S. & 871 & Lisbona, F. & 871 & Trifon, $\mathrm{S}$. & 889 \\
\hline Chen, X. B. & 829 & Liu, S. M. & 829 & & \\
\hline & & Lobley, G. E. & 829 & Vaisman, N. & 889 \\
\hline Davies, D. & 881 & López-Aliaga, I. & 871 & van Milgen, J. & 7 \\
\hline Duguid, T. J. & 819 & & & & \\
\hline Dunshea, F. R. & 809 & MacLeod, N. A. & 829 & White, A. & \\
\hline & & Makkar, H. P. S. & 897 & Woodhead, S. & 881 \\
\hline Gains, $N$. & 851 & Meier, M. K. & 851 & & \\
\hline Gómez-Ayala, A. E. & 871 & Moeglen, C. & 851 & $\mathrm{Yu}, \mathrm{S}$. & 63 \\
\hline
\end{tabular}




\section{British Journal}

\section{of Nutrition}

\section{VOL. 73 NO. 6 JUNE 1995}

\section{CONTENTS}

\section{Editorial}

Confounded by time. D. A. T. Southgate

Models for ruminal digestion

Models based on variable fractional digestion rates to describe ruminal in situ digestion. Jaap van Milgen \& René Baumont

Ractopamine metabolism

Responses to homeostatic signals in ractopamine-treated pigs. F. R. Dunshea \& R. H. King

Bioavailability and polyamine content of food

The importance of dietary polyamines in cell regeneration and growth. Susan Bardocz, Tracey J. Duguid, David S. Brown, George Grant, Arpad Pusztai, Ann White \& Ann Ralph

Protein intake and protein turnover in sheep

Effects of long-term protein excess or deficiency on whole-body protein turnover in sheep nourished by intragastric infusion of nutrients. S. M. Liu, G. E. Lobley, N. A. MacLeod, D. J. Kyle, X. B. Chen \& E. R. Ørskov

Modulation of oxidative stress by $\beta$-carotene

Modulation of oxidative stress by $\beta$-carotene in chicken embryo fibroblasts. Susan M. Lawlor \& Nora M. O’Brien

Orlistat and triacylglycerol absorption

Effect of the lipase inhibitor orlistat and of dietary lipid on the absorption of radiolabelled triolein, tri- $\gamma$-linolenin and tripalmitin in mice. Dorothea Isler, Christine Moeglen, Nigel Gains \& Marcel K. Meier

Tin intake and copper metabolism

High tin intake reduces copper status in rats through inhibition of copper absorption. Shiguang Yu \& Anton C. Beynen

Intestinal resection and iron metabolism

Effects of intestinal resection, cholecalciferol and ascorbic acid on iron metabolism in rats. S. Hartiti, M. Barrionuevo, I. López-Aliaga, F. Lisbona, I. Pallarés, M. J. M. Alférez, A. E. Gomez-Ayala \& M. S. Campos

Vitamin D in Asian mothers

Vitamin D deficiency: a concern in pregnant Asian women. Mazin Alfaham, Stuart Woodhead, Gunilla Pask \& David Davies

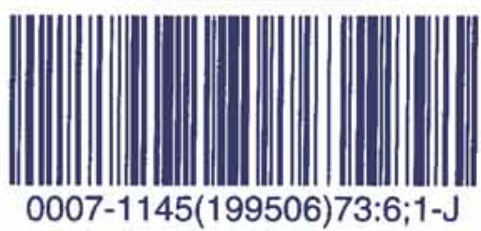

